\title{
INTERNATIONAL MISSIONARY CO-OPERATION
}

\author{
By JOHN R. MOTT, LL.D.
}

Ar first thought it might seem that the present is the least favourable time to draw lessons or to reach conclusions regarding international co-operation. Without doubt, the present is in some respects the most difficult time internationally the world has ever known. It is characterized by suspicion, irritation and lack of fundamental unity. The events of recent years have broken most international bonds. Intercourse and intercommunication have been more seriously interrupted than in any period within man's memory. All this has necessarily profoundly affected the progress of international co-operation in the realm of Christian missions as in every other sphere. On further reflection, however, is it not clear that the very fact that the international relations of the world in recent years have been and still are in such a critical state accentuates the need and importance of restudying the whole subject? Possibly better now than at any previous time, we are in a position to estimate the relative strength of the various factors and influences working for and against missionary co-operation, to recognize international shortcomings, to realize sins of omission and of commission, and to lay to heart the lessons which should be learned from recent bitter and humiliating experience. A very special responsibility rests upon all who are in a favourable position through past experience, through present contacts or through a sense of international obligation to do all in their power to suggest a wise and helpful lead. In what international group have we the right to expect an earlier resumption and strengthening of international relations than in missionary circles? 
These are the circles that have always claimed to deal with the world as a whole and to hold world horizons. A world distraught needs, nay, justifies, the most earnest endeavour and the deepest sacrifice to bring in a new and better day. Missionary leaders must show the way. Amidst all the discord and strife in international affairs may be seen the Son of Man. He speaks the words of calm and guidance. Is it not the call of this very hour for the leaders of the missionary movement the world over to heed His word and to dedicate themselves to the sacred task of ushering in a new era of international missionary co-operation?

\section{Considerations in Favour of Co-operation}

International missionary co-operation is demanded to counteract the recent marked growth of divisive forces in the world. All other arguments which may be advanced in favour of the drawing together of the Christian forces are accentuated in the present world of misunderstanding, suspicion, friction and strike. As a result of the war one finds a new and stronger alignment of national and racial prejudice among the peoples to whom the missionaries go. This necessitates a more effective union on the part of the missionary forces. The missionary movement has a marked contribution to make toward international goodwill. Through promoting right international and interracial relations it can accomplish wonders toward overcoming the disillusionment, pessimism and reaction which have come in the wake of the war and in that of the unsatisfactory peace negotiations. Effective international missionary co-operation will inevitably result in the development of the international missionary spirit and will furnish the principal bulwark in support of international justice and racial goodwill.

If the Church neglects to give adequate expression to its international character through the failure of the missionary forces of the nations to co-operate, the testimony and success 
of the Church will be seriously impaired. The ultranationalism which emerged in the war is contrary to the ideals and teachings of the New Testament. It is to be feared that a materialistic and selfish national spirit is growing in all parts of the world. Such a spirit is without international outlook and, unless Christianized, is destined to imperil the world. Unless the principles of Christ can be successfully applied to international relations, Christianity is clearly inadequate to deal with the present world situation. Missionaries have always preached 'Love your enemies,' but some are still under the yoke of unchristian patriotism and racial superiority. If we cannot have real international missionary co-operation, what ground have we to expect that there can be any kind of international cooperation which will unify mankind; and if we have other forms of international co-operation without being able to achieve international missionary co-operation, what other conclusion can be drawn by the outside world than that the Church has lost its way and has vacated its true spiritual leadership? Thus the future position of organized Christianity, as well as of civilization, is involved. How essential it is, therefore, that the missionary movement, through general international co-operation, should afford a living and indisputable demonstration that Christianity transcends nationality!

There is need of emphasizing as never before the truly catholic nature of the Christian Church, and this may be made more apparent and convincing through co-operation on the part of the world missionary forces than in any other way. The early Christians made it clear that the Christian Church brought men into a fellowship which included all nations and races, and this contributed greatly to their world-conquering power. These 'first Christians looked upon themselves as a new race-a people of God, united in a bond before which earthly distinctions faded.' In reality, the Church of Christ to-day consists of a body of people called out of the various nations, being united by 
the gift of a common life in Christ. Hence, not to strive for and to realize a practical working co-operation among ourselves in fields of common labour is a falling short of the vision and design of Christ.

Never before did the missionary task seem so large, so baffling, so beset with dangers. Never before did the Christian forces and leadership seem so inadequate. It is a startling fact that it is entirely possible that in this critical and fateful hour the Christian forces may fall short simply through failure to combine their efforts. At such a time only the mobilized and united wisdom and experience of all forward-looking leaders of all nations will suffice.

There are conditions, problems and demands in the modern world affecting the foreign missionary enterprise which can be dealt with successfully only by common international action. For example, the question of religious liberty and likewise that of missionary freedom have once more become live issues, and these ancient battle-grounds may have to be fought over again in the years just before us. Moreover, only by international missionary co-operation can the Christians of the world make adequate protest against the threatened selfish exploitation of peoples and resources.

The magnitude, complexity and cost of the world missionary program, the relatively meagre resources in available funds and in highly qualified workers, and the extreme urgency of the situation due to post-war conditions imperatively demand international co-operative effort. In the field of Christian education alone this can be seen at a glance. The experience in certain fields like Japan and the growth of government educational systems on every hand make it clear that the Christian forces will not be able to establish, equip and staff efficiently even a minimum number of model denominational and national institutions that can hold their own in competition with government secular education. The only hope, yet it is an adequate hope, is for the missionary forces of the different 
nations to pool their experience and resources. Without doubt we have to-day confronting us in the non-Christian world, in every aspect of the wide range of missionary responsibility, a task which might well seem to lie beyond the reach of the combined forces of Christendom. Let us see to it that we do not fall short through any avoidablestill less through any wilful--lack of combination.

International missionary co-operation is essential to give full-orbed expression to the missionary message of the Church of Christ. Christ has not revealed Himself fully through any one nation or race. No part of mankind has the monopoly of His gifts. The help of every nation is necessary adequately to make known His excellences and to communicate His power. This has been well emphasized recently by Sir Arthur Hirtzel in these words : 'For as in Christ, who is the Head, there is " neither Jew nor Greek, neither male nor female, barbarian, Scythian, bond nor free,"-not because $\mathrm{He}$ is none of these, but because $\mathrm{He}$ is all of them-so the Church which is His body cannot be perfected until " they shall bring the glory and the honour of the nations into it "; that is to say, until the special characteristics of every race have been, not submerged, but brought to their individual perfection, in a perfect whole.' A corollary of this is that the Christians of every nation have the sacred right and should, therefore, have the opportunity, thus to express themselves. In view of the difficult international situation it will undoubtedly require nothing less than wise, patient and possibly prolonged effort to ensure that this right is secured for all nations.

The outstanding argument for international missionary co-operation is that Christians of all lands must thus show their unity in Jesus Christ, that the world may believe. To preach the brotherhood of man and then to stand aloof from each other on the foreign field or at home, or to fail to fraternize or co-operate, belies our teaching and creates the impression that Christianity, like other religions, has lofty ideals, but that the practice of its promoters shows 
that it is impracticable. International divisions among Christians have ever been a scandal and stumbling-block; but with the shrinkage of the world these have become more intolerable than ever. If we can forget that we are Americans, Englishmen, Frenchmen, Scandinavians, in the work of making Christ known to the peoples of Asia and Africa, we have gone a great way toward proving to those Asiatics and Africans, who are moved by facts, that the religion of Jesus Christ is the ultimate solvent of the racial alienations of the world and, therefore, the mightiest force operating among men. Just now, when there is on every hand new interest in internationalism, this great apologetic would have added timeliness and power.

A serious and resolute attempt to secure the far wider adoption of the policy of international missionary cooperation would make a powerful appeal to the new generation. We do well to remember that we have a new generation to win to the missionary program. Our appeal to it must be true to the demand of the modern day. We need to bring to the oncoming youth the heroic call of an immensely difficult and apparently impossible task, for this generation of all generations has been uniquely prepared for such an appeal. But to win their wholehearted allegiance, we must be able to show them that ours is a united task. Never has the lesson of the indispensability and victorious power of united planning and action been burned into the consciousness and anchored in the convictions of a generation as in the case of the young men and young women now living.

In view of considerations like these, is it not of supreme importance that leaders of the missionary movements in all lands should take initiative and put forth sacrificial, prayerful effort to achieve co-operation that is at once international and interracial as well as interdenominational with a view to triumphant Christian advance throughout the world? In view of the mind and wish of Christ, we should be ready for sacrifice and suffering in order to attain our ideal. As 
we come to face the difficulties in the pathway of the realization of our vision and to count the cost which must be paid, as in the case of the acquiring of any truly precious possession, we shall see that great as are the obstacles in our path, the arguments for international co-operation-for a common mind, for corporate policy and for concerted action-on the part of Christians of all nations are decisive.

\section{What Hinders and Imperils International}

Co-operation?

National narrowness, prejudice and ambition hinder. Among all of us there is not a little narrow provincialism. It is to be feared that now and then we are all guilty of harbouring a measure of depreciation or contempt for the ideals or distinctive traits of other nations. Too often we are unwilling to try to get the point of view of those of other lands. Inherent selfishness, self-satisfaction, indifference and inertia always stand in the way. There are also difficulties arising out of national traditions, susceptibilities and preferences. Any attempt of one nationality to dominate, either through lack of imagination or through lack of clear recognition of the valuable contributions other nations have to make, or through failure to show generous appreciation to other co-operating nationalities, is fatal to satisfactory co-operation.

Lending the aid or influence of the missionary movement or of missionary activity to further national political ends hinders. The idea of the Church or mission of any nation being used to advance the commercial or political interests of that nation is pernicious. It cannot be denied that both before and since the war such activity has taken place with the tacit or active approval of Christian leaders. The missionaries and the boards they represent are not out to further the political or economic designs of their own or of any other country. Governments now, as possibly at no time in the past, distrust the influence of missionaries 
of other nationalities. The attitude or practice of mixing missionary and worldly ends inevitably engenders distrust, and this absolutely prevents desired international co-operation. It should not be forgotten that commercial interests are often not unwilling to use missions to further private ends, if the missions, wittingly or unwittingly, are found usable to these ends.

Lack of clear recognition of the relation between national patriotism and true Christian internationalism hinders. Political propaganda during the war wrought havoc to honest thinking. It has led to an exaggerated nationalism. Co-operation must ever fail where Christians set nation or empire above the Kingdom of Christ, earthly aims above the heavenly purposes, national divisions above the oneness of the Church of Christ. We need a clearer vision of the Master -of the supremacy of Jesus Christ as Lord. If we have that, we shall not lose or weaken love of country, which is consistent with Christian faith, while our vision expands to take in the kingdoms of this world becoming the kingdoms of our Lord and of His Christ. Dominating loyalty to the Kingdom of Christ makes international missionary cooperation possible and inevitable. Unless we have this, the difficulty of effective, wholehearted co-operation with the rising native Churches on the mission field will increase rather than diminish. The thinking native Christian leaders more and more are making and will make this great intellectual and moral demand on the Christianity of the coming day.

Different national standards hinder. We are much further apart, we Christians of different nations and races, than we at times realize. For example, how widely do Anglo-Saxons and the people of certain continental countries differ in their conceptions of State, of Church and of society! It is difficult for the people of any country to harmonize, co-ordinate or combine their ideas and methods with those of other lands. Each nationality sees the strong points of its own particular system and is doubtful about those of others. We must learn to take account of the 
different temperaments, ideals, cultural backgrounds, professional standards and methods of work of the Christian leaders of different nationalities and races if we would bring about really effective co-operation. The failure to do this explains the lack of enthusiasm which is often manifested in early stages of international co-operation. It requires time to bring about understanding and to remove suspicion, fear and possible friction points.

Without doubt it often is difficult to understand and to work with people of other nationalities. To conclude, however, that it cannot be done is begging the question and missing the central point. We must live in unity with other nations if we are to fulfil the law of Christ. The truth is that each national type has its strong as well as its weak points. It follows that a combination of the strong points of all types, if dominated by the Spirit of Christ, will give a resultant force the most complete and effective. 'In practice,' says Mr Hoste of China, who has had as large experience of unifying workers of different lands as possibly any missionary leader living, ' it is sometimes difficult to overcome one's own prejudices and to bear with those of others ; but there is no other way of growing in fitness to influence and serve an increasing number of one's fellow-men. It is a small man who expects every one to fit in with his ideas. It is fatal to allow ineptitudes and limitations of another man to repel one. The fact that it does is a pretty sure evidence of one's own limitations and ineptitudes. Hence the vital importance, by God's help, of schooling ourselves to overcome these things and so be fitted to help a larger number. We simply cannot afford to draw back from co-operation with men of various national types; growth along these lines is a long, difficult and often painful process, but at all costs it must be attained, if the Church is to fulfil its mission.' Difficulties there are in working with men of other lands and races, but in the pathway of experience we find that many of them are a result of misconceptions and prepossessions which con- 
tact, sympathy, charity and a sincere attempt to appreciate other points of view speedily dissipate.

Pride or lack of humility-national, ecclesiastical or personal - is at the root of difficulties in the way of developing real international co-operation. Unless we have in us the mind which was in Christ Jesus who emptied Himself, we cannot hope to lay deep and secure foundations for a great international structure. Unless we are ready to believe that others may achieve as great or greater things, even with different methods and along different lines, we shall not be able to learn from them and shall not be prepared to co-operate usefully with them. This may seem like a truism, but it is not enough taken to heart. We should always be ready and determined to learn from others, including the smaller nations and the more obscure societies.

An unfavourable attitude towards co-operative movements on the part of the supporting societies or churches at the home base has a very direct and deterrent bearing on the development of international missionary co-operation. While the difficulties of international co-operation are great, they are sometimes less serious than the difficulties experienced by missions or Christian bodies of the same country in attempting to work in union or co-operation. Thus the denomination is at times more of a problem than the nation. The conviction which the leaders of some denominations hold as to the validity of certain dogmatic positions and as to the unwisdom of jeopardizing their ecclesiastical position by sharing in administrative or co-operative activities with other Christian groups, stands in the way of co-operation. The nature of the ecclesiastical organization of certain denominations, having, as they do, no centralized body to speak or act officially on behalf of the entire communion, even though they recognize the necessity of a combined impact of the Christian forces upon the ignorance and evil of the world, is unmistakably a handicap to co-operation. The ambitions and plans of some denominations, especially 
when backed by vastly disproportionate financial resources, may, and at times actually do, seriously interfere with the symmetrical and healthy development of international as well as of interdenominational co-operation. The selfish or unwise action of an individual missionary society may make co-operation for other societies of that nation difficult, if not impossible. The progress of the international cooperative movement is like unto that of a fleet of battleships, the speed of which is determined largely by that of its slowest unit. Thus a large or influential denomination in one national group may, by its lack of vision or by its extreme conservatism, retard the whole international cooperative movement.

The fear entertained by the missionary forces of certain nations, races or denominations that the international missionary co-operative movement means the development of some super-board or powerful, highly centralized agency which will tend to fetter or limit their own autonomy or freedom, has at times stood in the way of their fullest identification with the movement. The fear is based on a misconception, for the co-operation in view represents a co-ordination or correlation of the missionary forces and in no sense their amalgamation, or the building up of a centralized agency with overhead authority. The bringing about of a useful co-ordination of independent and autonomous parties calls for careful study and taking into consideration the various characteristics, gifts and tendencies of each party.

The greatest difficulty thus far has been the war. It broke on the world at the most hopeful moment in the history of Christian co-operation. With startling suddenness it interrupted this most significant and promising development, in some places brought it to an absolute standstill, and everywhere retarded it. The bad effects have not yet passed away and will not, it is feared, for many a long year. It has left behind distrust, estrangement and aloofness between nations. It created serious divisions 
among the Christian forces themselves in the different nations. It engendered feelings which nothing short of a wonder-work of God can conquer and transform. While the war has made the missionary task far more difficult, it has also made it appear infinitely more desirable and necessary. Time must be given for the wounds to heal. It would be a mistake to try to force the process. We must not speak too much of friendship; acts of friendship are better than words.

The achieving of international co-operation is a matter of personality rather than of nationality. A large part of the difficulties which have arisen are due to personalities. Great care, therefore, should be exercised in choosing those who are to occupy positions of leadership in any union, organization or institution.

Isolation is at once a barrier and a challenge to international co-operation. Without doubt, ignorance due to isolation is at the root of much international misunderstanding and lack of concerted action. There is no minimizing the reality of the difficulty presented by vast distances. The comparative rareness of intercommunication between countries, the infrequency of visits, make it difficult to keep in touch and to communicate the right atmosphere. Still, the marvellous improvement in means of communication during the last two decades has, comparatively speaking, made oceans and continents seem more like mere details. Much more serious than geographical isolation is the isolation due to ignorance of each other's languages. The curse of Babel abides with us. The Anglo-Saxons probably suffer more from this than does any other nation, and certainly more than they themselves seem to realize. The language difficulty prevents English and French speaking peoples, especially, from receiving the rich contribution of such peoples as the Dutch and Scandinavians. Moreover, how little other nationalities know of the two hundred years of German missionary experience! Much of the grave misunderstanding between Germans and the missionary 
leaders of allied nations was due to their not understanding each other's language and not having access to each other's literature. The reading of the missionary workers in any given country has been confined too largely to the periodicals printed in their own tongue. What a loss any missionary or missionary administrator suffers in not being able to peruse the Allgemeine Missions-Zeitschrift, which for a generation has stood with so great ability for co-operative and ecumenical principles. There is another kind of isolation, that due to aloofness of spirit. Even when people of two different nations are living side by side and are more or less familiar with their respective tongues-as, for example, is the case between missionaries and the people whom they have gone to serve-the finest co-operation is often hindered as a result of lack of intimate intercourse with each other. In China, men like David Hill, Hudson Taylor and Timothy Richard have shown the boundless possibilities of close identification with the people of another nationality and race.

The financial difficulty in international co-operation is a very real one. Almost every union or joint project is handicapped or embarrassed at this point. The International Missionary Council and the various national missionary bodies at the home base and on the mission field stand in need of larger and more dependable financial support. Inadequate financial support is answerable for the relatively slow rate of progress in the development of international missionary co-operation. It is difficult to get mission boards to meet the expense of union enterprises in view of the pressure of other and better understood demands. When boards have funds they naturally feel responsible for the spending of them, and hesitate to spend for co-operative work money given for denominational work. The varying scales of expenditure of different national groups presents another aspect of the financial problem of co-operative effort and calls for difficult adjustments. In fact, this problem has not in many cases been 
satisfactorily solved. In case of some joint projects, such as union universities, the inability of the boards of certain nations to furnish their proportion of funds may be a source of irritation. At times union schemes are launched on a certain financial basis, and then at a later stage (often in a short time and in direct contravention of promises made in the initial negotiations) the natural expansion of the institution necessitates a complete revision of the demand or financial requirement; in other words, sufficient provision was not made for the future when the scheme was first presented to the co-operating bodies. These are only a few illustrations showing what a practical problem is this one of finance.

Lack of comprehensive and conclusive thinking by the Christian leaders in the different countries on the subject of co-operation explains why the Christian forces of these nations are not manifesting a more triumphant unity. How few have thought out the aims, principles and factors which determine the most fruitful co-operation! It is to be feared that many of us use identical terms with different meanings. How few have familiarized themselves with the large and ever-growing volume of experience, both favourable and unfavourable, in the sphere of interdenominational and international co-operation! With such literature available as The International Review of Missions, the Reports of the Edinburgh Conference Commissions and of the Continuation Committee and other conferences held on the foreign field in the last decade, and the records of national and provincial missionary councils, such ignorance is inexcusable.

The secretaries and members of mission boards who are internationally minded and who are intellectually and spiritually equipped for establishing and maintaining international relationships, are so burdened with administrative and other duties, or have so failed to organize their time, that they do not give the time and attention to co-operative effort which it merits and demands. Each worker is busy 
doing what he considers to be the next most urgent task, and, as a rule, is in arrears. Then when we meet in conference or committee and deal with some aspect of cooperation and pass resolutions, we too often expect some one else to give them effect. There is no disguising the fact that the achieving of successful co-operation requires much time, especially in its earlier stages, and many shrink from making this indispensable contribution. They would prefer to pay in any other coin. Unquestionably, however, this is the most highly advantageous use of time in the entire sphere of Christian statesmanship.

Failure in the spiritual life is the most fundamental weakness in international co-operation. We use the word fundamental advisedly because, if this weakness be overcome, most of the other difficulties in the pathway would be swept away. We do not take time to develop a real international fellowship through waiting upon God for His guidance instead of rushing in with eager and heated discussion. Time is saved in the long run by allowing time for men to grow out of their national spirit into one truly international. It seems to be necessary that at times we travel the path of humiliating, apparent failure that we may come into a realizing sense of the supremely difficult character of the problem of drawing together the workers of different lands and races and, therefore, of our utter dependence upon God. Efforts for missionary co-operation between nations have invariably failed wherever they did not rest on the solid ground of deep, spiritual unity. Doubtless some nations are more in danger than others (but what nation can wisely neglect to be vigilantly and humbly on guard ?) of relying on strong organization or brilliant leadership or the power of money rather than upon the limitless power of God.

As we call attention to these among other difficulties, handicaps and causes of failure, it is clear that the pathway to the realization of efficient international co-operation is not an easy one. There is nothing to be gained by 
minimizing the existence and gravity of these hindrances. We shall never draw together, as Christ desires and as the world situation demands, unless we do face our difficulties frankly and deal with them courageously and thoroughly. We all admit that there have been disappointing failures in the realm of international missionary co-operation. It should be pointed out, however, that compared with other spheres of Christian activity, such failures have been relatively very few. It should also be emphasized that we are too ready to ascribe such failures to international rather than to personal causes. All the foregoing and many other difficulties only emphasize the importance and necessity of concerted planning and action on the part of the missionary forces of our day. As has already been said, it calls for difficult initiative and for prayerful, sacrificial, undiscourageable effort. Men must realize the tremendous worth-whileness of international co-operation as a result of much prayer and of catching the vision of Christ, or they will not pay the price.

CONDITIONS UNDERLYING SUCCESSFUL INTERNATIONAL Co-operatron

At the root of every satisfactory experience in international missionary co-operation is the deep conviction on the part of at least a few of the recognized leaders of the missionary forces of the nations concerned that the particular task to be accomplished is one of very real importance, and that it can be accomplished best, if not alone, through such international action. Coupled with this is another fundamental conviction, that of the unity in Christ of the true Christians of all nations. Beside this vital fact, all differences and points of controversy seem of minor importance.

A man placed at the head of any international co-operative enterprise or union institution should be well qualified for such international responsibility. He should 
be a man, whatever his nationality, who commands the esteem and confidence of all concerned. He should possess international outlook and understanding, international appreciation or breadth of sympathy and international courtesy. He should be teachable, courageous and patient. In a word, he should be a man of real insight and responsiveness. He must appreciate and be able to blend the distinctive contributions of men of different nationalities on his staff. He will regard them as mutually complementary. Thus points of difference become points of contact and help to interlock and bind together different important elements. Co-operation is successful in direct proportion to the extent to which the leaders and supervisory committees prove themselves to be working unselfishly for the good of all. A study of the development of Christian co-operation shows in many cases the powerful and unique influence of a few individuals possessing the qualifications here emphasized. In the light of experience, it is not too much to say that success depends largely on the personal equation of the leaders.

There should be mutual understanding between the leaders of the different national groups co-operating and a determination not to misunderstand. If in each country leaders can be found who will refuse to accept misunderstanding, who will always credit the other side with having a reason that has not been made clear, and who will constantly go out of their way to make explanations and to exercise forbearance-such leaders will hold entire constituencies in sympathetic relations and in harmonious cooperation with one another.

To ensure trustworthy co-operation, groups from different nations need to get into each other's presence from time to time, notwithstanding the difficulties of travel and the expense involved. Whatever overcomes isolation is a very direct help. Where there are differences of language as well as of national view-points, the contacts should be fairly frequent. In case of important 
union projects, it is desirable, as a rule, that managing committees meet at least annually. It is essential to maintain close international consultation during all stages of the evolution of plans.

The definite settling of policies in advance will obviate much friction and will greatly facilitate satisfactory international co-operation. There is a marked advantage in letting each co-operating nation be a party to the determination of a policy which is to govern them in common with others. Workers of that nation, who identify themselves later with the project, come in with the knowledge that the policy has not been settled without their nationals having been heard, and they are prepared to accept it loyally and to carry it out with full sympathy. So far as possible, controversial questions having their roots in home conditions should be removed from the jurisdiction of local bodies, such as boards of management on the field, and should be settled by the authorities at the home base. There will still remain enough problems and difficulties for the field groups. These should be faced frankly and be dealt with thoroughly.

Means must be found whereby the leaders who have had the advantage of personal contacts shall share with members of missionary societies or committees their own international vision, knowledge and sense of responsibility. This will be well worth all the difficulty and expense involved. Each society is now so occupied with its own immediate affairs as to be largely unaware of the possibilities and demands in the realm of international cooperation.

It is highly desirable that missionaries of one nationality, who are at work in the colony or territory of another country, should study in that country, or at least that they should by a visit establish intimate contacts with it. Last winter, for example, some twenty American, Swedish and Norwegian missionaries studied in Paris several months and had almost daily contacts with the Paris Missionary Society. ; This prepared them for much closer co-operation 
when they proceeded to Madagascar, Cameroon and the French Congo.

There should be a well-thought-out financial policy to provide for the adequate support of a co-operative undertaking, and the different national groups should assume their proper share of the financial responsibility. This applies not only to international committees for the furthering of co-operative effort-such, for example, as the Continuation Committee of China-but also to such union institutions as universities, colleges and hospitals. It is gratifying to note that an increasing number of mission boards, especially in Great Britain and North America, have, after careful consideration, begun to include in their annual budgets definite appropriations toward such international committees and union work as an essential part of their program. The matter of co-operative missionary finance is still, in the case of certain boards, in an experimental stage. The time has come when it should be thoroughly discussed and settled once for all by each agency. The general plan for meeting the expense of co-operative activity, based on experimentation and experience of the past few years, might be outlined as follows : (1) Each missionary society, or each national group of societies, should contribute its pro rata share of the budget of joint committees to which it is related at the home base and on various mission fields. A fair and equitable basis must be worked out in each case. Having decided what the share of each nation should be in a given enterprise, it should be left to the boards in each country to determine how best to distribute the amount among themselves. (2) Each society, or each national group of societies, should make additional contributions, also on a pro rata basis, toward other special union projects which, in conjunction with other societies, it desires to promote. (3) To allow for societies which, for one reason or another, may be unable to assume their share of the financial responsibility, or to help in the difficult pioneer stage of a union effort when 
its support is being domesticated among the societies and churches, it will probably be necessary to enlist supplemental gifts from individuals. The group of persons to be thus approached should be approved by leaders of the regular missionary societies which may be concerned. What does the co-operative movement not owe to the large-minded, far-sighted, generous donors who, by their discerning, prompt and liberal support, have done so much to make possible the achievements of the past! It is no exaggeration to say that they have advanced the movement by decades. To ensure the democratic character of all such work and its proper control by the mission boards and churches, the ultimate aim should be to have it supported entirely and as soon as practicable by these constituencies.

In case of launching a union educational institution or other international co-operative project in a given mission field, it is worth while to devote special effort so to plan the work that it will not be an arbitrary superimposing of a foreign system, but rather will be fully adapted to the country which it is desired to serve. There will then be less ground for any feeling that an effort is being made to turn a co-operative organization into an institution of a particular foreign country and incidentally to enhance the prestige of that country.

An effort should be made to strengthen the indigenous element in any international co-operative organization in a particular country. This will tend to lessen the importance of national differences as between co-operating bodies. As an institution, for example in China, cannot be American, British or French, probably most of its supporters will be glad to see it develop normally as a Chinese institution. In this connexion it should be stated that it will be difficult to get the utmost co-operation unless bodies at the home base are willing to leave a large amount of control in the hands of those on the field, including nationals of the field area. This is even more true of international than of interdenominational co-operation. 
In the case of committees responsible for the guidance of international co-operative work, it is most desirable to secure unanimous action or approval on all important questions. The overruling of a sincere minority by a majority is not conducive to unity which, as a rule, would be better preserved by united prayer and by waiting until a general, if not an absolute, unanimity of opinion is secured. The best results are obtained when a genuine spirit of Christian love and service prevails and the opposite spirit of lordship and bondage is kept out. The strength of the individual and corporate religious experience largely determines the measure and helpfulness of mutual cooperation.

\section{Guiding Principles in International Co-operation}

More important even than practical ways and means are certain guiding principles which should govern the attitude and practice of those who seek to develop international missionary co-operation.

1. An adequate and satisfactory international co-operative movement should be officially representative of the constituencies in the co-operating countries.

2. There should be the fullest degree of liberty for each nation entering into the co-operative arrangement.

3. At the same time there should be a correlation or co-ordination of the various national co-operating forces to avoid confusion and to ensure that their combined experience, wisdom and dynamic purpose are brought to bear upon the common problems.

4. Whatever is done should be done in consultation and openly.

5. There should be a sincere determination to understand the different national view-points and problems.

6. The members of each national group should, with open-mindedness and generosity, welcome the maximum contribution of the other national groups. 
7. Identification with the interests and aspirations of the people served is essential.

8. The cultivation of friendship should be a guiding principle in furthering the common end.

9. The principle of service should be given right-of-way - that is, the largest and most Christlike service to all men of all nations and races should be a determining consideration.

10. The most distinctive principle of all is that everything in the range of the co-operative program and activities should be considered and dealt with from an international point of view.

11. Whatever co-operation is undertaken should be carried through so thoroughly that it will give confidence and stimulate to ever wider co-operation.

How may the International Misstonary Council best foster International Missionary Co-operation?

When the World Missionary Conference at Edinburgh appointed a Continuation Committee, it indicated as one of its duties 'to confer with the societies and boards as to the best method of working towards the formation of a permanent international missionary committee.' Within the last two or three years it became increasingly clear to members of the Continuation Committee and to other missionary leaders that the time had come when definite steps should be taken to give full effect to this instruction. The officers of the Continuation Committee, therefore, called a representative international conference which, as readers of the Review will recall, met at Crans, Switzerland, in June 1920 to consider this together with other large questions of international concern. The plan for a permanent international organization, drawn up by the Conference, was during the subsequent year submitted to the national missionary organizations of different countries. The reports from the different nations show 
that the plan met with the general approval of the national missionary bodies of nearly every country.

The first official meeting of the new International Missionary Council was held at Lake Mohonk, U.S.A., last October, and is reported elsewhere in this number of the Review. The Council is established on the basis of the principle laid down several years ago by the Continuation Committee: "The only bodies entitled to determine missionary policy are the missionary societies and boards and the churches in the mission field.' Its membership of approximately eighty persons is appointed largely by the national missionary organizations of the different countries, although provision is made for the co-opting of a limited number. The establishing of this organic relation of the Council to the official or authoritative missionary organizations of the different nations constitutes one of the most important improvements over the plan necessarily followed by the Edinburgh Conference in constituting the Continuation Committee. Another marked improvement is that of including in the new International Council official representatives (two-thirds of whom shall be natives) of the national bodies on the mission field.

As the International Missionary Council stands on the threshold of its important service, and as the missionary forces of the world confront a new era, it may be well to consider ways in which this new servant of all the boards, societies and churches may best foster international missionary co-operation. The answer, with due regard for the functions and powers of the Council, must work out in the convictions, desires and hopes of discerning Christian leaders in all parts of the world.

All the members of the International Missionary Council should realize and accept the heavy responsibility involved in membership, should take initiative within the sphere of their respective national bodies and, where necessary, should reshape their personal programs so as to give as much time and to devote as much effort as possible to creat- 
ing a solidarity of feeling among the Christians of different lands and to furthering international thinking and action. The task to be accomplished is so great and urgent that it cannot be achieved by the officers alone. The Council as a body must also develop capacity for corporate international thinking. To this end it is highly important that its members come together, although at not too frequent intervals, to form a real fellowship and to afford an international lead among the all-too-divided missionary forces of the world. The changes that the work is now undergoing are so constant and stupendous that the desirability of biennial meetings would seem to be self-evident.

The International Missionary Council should also be put in a position to stimulate common discussion, united original research and thoroughgoing study of large and significant missionary questions. These processes are limited only by lack of leadership and lack of funds. Such intensive studies will accomplish large and enduring results for the worldwide movement.

The Council may well serve as a clearing-house of essential missionary information. To this end it must increasingly equip itself with knowledge of all aspects of the world situation and of the world missionary movement. It is in a position, as no other body is, owing to its representative personnel and its large influence, to render this international service. An office with properly classified data of the missionary experience of all nations and of all constituent missionary bodies would be of increasing value to missionary thinkers, writers and administrators of all nations. Inevitably the Council will become more and more a repository of wise counsel to which missionaries, board secretaries, church leaders, special commissions and investigators will turn. Its advice is destined to have a large and, at times, a determinative influence upon missionary policy.

Through The International Review of Missions the Council will continue to afford a sound, far-sighted lead 
to missionary thinking, outlook and standards all over the world. The paper should deal not only with what the mission boards and the Christian leaders on the mission field desire to have taken up, but likewise with vital matters which the missionary situation, judged internationally, demands. It would be difficult to estimate the unifying, vitalizing and vision-giving power which the Review may thus exercise.

The International Missionary Council should feel a sense of responsibility for the whole world. If it does not, what body will? It is the lineal descendant of the Continuation Committee, and the distinctive responsibility of that Committee, as the name implies, was to perpetuate the vision and spirit of Edinburgh. All who were in any way related to that Conference and the work of its Commissions know that it tried honestly to face the wholeness of the task. Its first Commission dealt with the problem of carrying the Gospel to all mankind. The present is the last of all times to let the world-wide vision fade or to permit the burden of responsibility for making the knowledge of Christ accessible to all mankind fall off.

The Council may also well use its influence to further the co-ordination and to improve the methods of the survey work of different national bodies. It is desirable to bring about such verification of statistical returns as will facilitate comparison.

The most distinctive function of the Council is that of establishing living contacts between those of different lands who are devoting themselves to the world-wide extension of Christ's Kingdom. Few things can be done which will prove to have more highly multiplying influence for bringing in true Christian internationalism than the drawing together in enduring fellowship small international groups of leading minds. In all the Christian centuries such groups have afforded the conditions which in turn have made possible the releasing of world-conquering spiritual power. 
A body like the International Missionary Council, whose field of operation is literally the wide world, must make use of the conference method to accomplish its comprehensive purpose of co-ordinating the missionary activities of all nations and of furthering united action. Owing to the problem of distance and the consequent cost in money and in time, these international conferences should, as a rule, be small, and should not be held save when the object in view cannot be achieved in any other way. At times the conferences should deal with a given national or international area, as was the case in the chain of international conferences conducted in 1912-3 by the Chairman of the Continuation Committee. At other times conferences may be called to deal with certain pressing problems of international import, such as were dealt with at the conference held in Crans last year. Probably not a year will pass when it will not be extremely important to resort to this means in order to safeguard vital missionary interests or to promote necessary joint action on the part of the missionary forces of different nations. Thus far no method has been discovered which can take the place of this one. The Council, therefore, in planning its international service may well keep this in mind and be prepared to overcome the inevitable difficulties involved.

The question often arises, When will the next World Missionary Conference be held ? It will be recalled that one of the duties assigned to the Edinburgh Continuation Committee and passed on by it to the new International Missionary Council was 'to call another World Missionary Conference if and when this should be desirable.' Undoubtedly there are reasons why such a conference is more needed now than was the case in 1910 and why larger effect could be given to the findings of such a conference. On the other hand, the very real difficulties arising from the present international situation and from the widely prevailing post-war conditions make it seem inexpedient to project the plans for a world conference at the present 
time. The Council, owing to its very representative and influential international personnel, will naturally consider that it is within its function to keep its hand on the pulse of the world situation and to determine in advance just when there should be called together a conference which we may well believe is destined to exert an even greater influence internationally than the one which met on the heights of Edinburgh at the beginning of the last decade.

One of the most effective and, on the whole, economical means which may be employed by the Council is that of facilitating the sending by the national bodies of international deputations to the mission field. Two splendid illustrations, to which reference has already been made in the Review, are the Commission on Village Education sent to India last year and the Educational Commission now at work in China. Another equally good example is the work of the Commission under the leadership of Dr Thomas Jesse Jones, which has recently accomplished such a valuable work in Africa. In such work everything depends on the personnel. It is also important that the deputation have ample time at its disposal, first, to make adequate preparation; secondly, to pursue its investigations and to formulate its report; and thirdly, and of possibly equal importance, to visit, on its return, as many as possible of the boards or societies which are in a position to give largest effect to its findings and to enlist their practical co-operation in doing so. It should go without saying that there must be a fund sufficient to meet expenses. Commissions, however, are at times seriously handicapped for want of money, not so much to meet their own personal expenses as to provide necessary secretarial help, to meet the expense involved in calling into conference workers and others qualified to give necessary information, and to meet the cost of the publication of results.

It is highly desirable that the Council from time to time send forth special visitors or messengers to different fields. In some cases the visitor should go in the name of 
the Council, in other cases under the auspices of the national missionary organization of the country to which he goes. The annual visits of the secretaries of the Council to North America and the Continent are typical of service much needed and desired. Members of the Council also should be called upon to represent it on important international errands. In passing, reference should be made to the valuable service which the Council can render by being on the alert to discover and then to help to relate leading minds in all nations to the large international questions. The need is imperative in almost every country of bringing to bear on the international problems from the Christian point of view the best thought of leading men who now through preoccupation are concerned solely with national or denominational activities.

The raison d'être, the very genius of the International Missionary Council, as its origin, name and purpose indicate, is the realization of international co-operation among the missionary forces of the world. Whatever else it fails to do, it must not fail to make definite advances in this direction each year. It stands for the prosecution of work which can be better done in union than in separation. The very existence of the Council and its coming together at intervals will do much toward realizing the desired end. The Council, however, should become the recognized authority on all that pertains to international co-operation in the sphere of Christian missions. It should carry on a continuous study of organizations and undertakings in which two or more nations are united, and be ready to suggest measures and methods by which such projects can be conducted most efficiently. It should continue to publish in the Review and elsewhere studies dealing with this subject which is of living concern to every nation. A recent scanning of the files of missionary periodicals of all nations and of missionary conference reports shows how little of real value on this subject exists in print; and yet, reflect on the wonderful developments 
of recent years in this sphere and also on the living importance of the subject. The Council should be on the alert to discover and unfold evidences of the need for international co-operation. It should constantly encourage existing co-operative enterprises and further the launching of new ventures.

In particular, the International Missionary Council should help to develop and strengthen national missionary organizations in the different fields, both at the home base and on the mission field. The Continuation Committee had a principal part in creating such bodies on the mission field and likewise had a marked influence in promoting similar organizations in western nations. In 1910 there were only two such bodies in the world. Now there are not less than twelve. A number of others are imperatively needed. The importance of furthering these organizations is seen when we remind ourselves of the contributions already made. It is believed that these national bodies are only in the initial stage of their development and that with wise guidance and adequate support they are destined to exert a profound influence on the ideals, efficiency and fruitfulness of the Christian movement in every land.

From time to time there will be large and vitally important co-operative tasks which the International Missionary Council must perform on behalf of all boards, churches and nations. It is worth all that has been expended in money, thought and sacrifice upon the Continuation Committee that it was able to deal, on behalf of the missionary forces of the world, with any one of a halfdozen large issues thrust upon its attention by the war. The services that the new Council actually accomplishes and lays at the feet of the national missionary bodies will be the greatest argument which can be given for international missionary co-operation.

Doubtless the promotion of united intercession will come to occupy a larger and larger place in the activities of the Council. If it be true that the most successful international 
missionary movements have grown naturally out of a preexisting religious unity, then surely the desired international solidarity on the mission fields and at the home base and the greatly longed-for outpouring of superhuman love and power, are largely dependent on the establishment of a strong spiritual bond between the leaders of the Christian missionary forces in all lands. We should lean heavily on the spiritual character of international co-operation. Only as we approach the mind and heart of Christ do we gain the spiritual dynamic essential for the realization of international co-operation. Only as a pronouncedly spiritual movement is deep is international fellowship possible, and therefore we must make our supreme appeal to spiritual motives, and our chief emphasis must be placed on those spiritual processes, notably intercession, which in all generations have exerted the greatest unifying and vitalizing influence. In times and experiences of impossible difficulty (and we are living in such days) it is well to pray together before attempting to act together in matters of policy. Nothing does so much to unite as praying together. This was most evident at the recent meeting at Lake Mohonk where in each day's sessions united intercession was given its true central place. What have we to do quite so important as the systematic promotion of a deep-rooted, spiritual unity on the mission fields and at home? Let our Council be careful to give the warning again and again that the primary need is not international machinery, but a spiritual organism-spiritual because grafted into the living Christ.

JohN R. Motr 